\title{
La representación del barco en los templos medievales de la fachada atlántica de la Península Ibérica ${ }^{1}$
}

\author{
The representation of the boat in the Medieval \\ temples of the Atlantic front of the Iberian \\ Peninsula
}

\author{
Isabel RUIZ DE LA PEÑA GONZÁLEZ \\ Universidad de Oviedo
}

Recibido: 15-V-2014 / Aceptado: 27-VI-2014

RESUMEN: El punto de partida de esta investigación se encuentra en el relieve de un barco de vela labrado en un arcosolio del interior de la iglesia parroquial de Santa María de Concejo en Llanes (Asturias). El descubrimiento de esta iconografía y su ubicación aislada en el templo nos ha llevado a seguir el rastro de un tipo de representación semejante en las iglesias medievales del litoral atlántico. Entre los escasos ejemplos encontrados destaca por su similitud con la embarcación asturiana una nave esculpida a una altura considerable en un contrafuerte de la fachada de la catedral de Oporto. Esta investigación pretende contextualizar e interpretar iconográficamente éstas y otras representaciones de naves que se conservan en algunas villas portuarias medievales del litoral atlántico igualmente prósperas en la Edad Media.

Palabras clave: Iconografía, Barco medieval, Cofradías, Comercio pesquero, Vías atlánticas, Villas portuarias medievales, Catedral de Oporto, Llanes, Patrocinio constructivo.

Résumé: Le point de départ de cette recherche réside au relief d'un bâteau à voile sculpté dans un arcosolio de l'intérieur de l'église paroissiale de Santa María de Concejo de Llanes (Asturies). La découverte de cette iconographie et son emplacement dans le temple nous a amené a suivre la piste d'un type de représentation pareil dans les églises médiévales de la côte Atlantique. Parmis le peut d'exemples trouvés on peut remarquer a sa ressemblance avec le bateau asturien, un navire sculpté à une hauteur considérable dans un contrefort de la façade de la cathédrale de Porto. Cette recherche vise à mettre en contexte et interpréter iconographiquement celles-ci et d'autres représentations de navires conservés dans certaines villes portuaires médiévales sur la côte Atlantique aussi prospères au Moyen Âge.

Mots clefs: Iconographie, Bateau médiévale, Confréries, Commerce du poisson, Routes de l'Atlantique, Villes portuaires médiévales, Cathédrale de Porto, Llanes, Patronage constructive.

${ }^{1}$ Esta investigación parte de una comunicación inédita, presentada al congreso Portugal e Castela na
Idade Média, que tuvo lugar en la Universidade Portucalense Infante D. Henrique (Porto) entre el $17 \mathrm{y} \mathrm{el}$ 


\section{A Juana María Gil López}

Quanto ivan las naves más adentro entrando, ívanse los peligros tanto más embargando.

(J. CASAS RIGALL (ed.), Libro de Alexandre, Madrid, 2007, núm. 2.301)

La iglesia parroquial de Santa María de Concejo se localiza en el corazón urbano de Llanes, una de las villas costeras más pujantes de Asturias, en la costa Cantábrica española, a fines de la Edad Media². Conserva un relieve labrado en uno de los sillares de un arcosolio del interior que representa un barco de vela, oculto actualmente por la imagen barroca de un Cristo yacente. El descubrimiento de este motivo y su ubicación aislada en el templo nos llevó a seguir el rastro de un tipo de representación semejante en la arquitectura religiosa medieval del entorno más próximo. Pero la ausencia de ejemplos parecidos nos impulsó a ampliar el ámbito de investigación a la costa cantábrico-atlántica peninsular, encontrando algunas representaciones similares en la arquitectura cultual, que se complementan con otras embarcaciones esculpidas en edificios civiles bajomedievales. Entre los primeros destaca el relieve labrado en el contrafuerte de la torre N. de la fachada W. de la catedral de Oporto, que representa una embarcación muy semejante a la que alberga la basílica asturiana, situada a gran distancia, pero igualmente en uno de los puertos atlánticos más prósperos de la Península Ibérica durante la Edad Me-

19 de marzo de 2004. El interés personal por la iconografía del barco en la Edad Media nos llevó posteriormente a proseguir la búsqueda de nuevos ejemplos, no sólo esculpidos en piedra, sino también representados en otros soportes y con otras técnicas artísticas: fresco, miniatura, sellos, monedas, tejidos, etc., cuyo contraste con las fuentes escritas y arqueológicas disponibles nos ha permitido exponer, en la presente publicación, unas conclusiones sobre el alcance y las posibles funciones de este motivo iconográfico.

2 J.I. RUIZ DE LA PEÑA SOLAR, “Notas sobre la actividad comercial en las poblaciones de la costa asturiana (siglos XIII y XIV)", Boletín del Instituto de Estudios Asturianos, no․ LX, año XXI, 1967, pp. 101-112. dia. Finalmente, a medio camino entre uno y otro enclave, encontramos dos naves esculpidas en un sepulcro pétreo conservado en la iglesia gallega de Santa María a Nova, sita en el importante enclave pesquero de Noia, en la costa atlántica gallega, villa con una próspera actividad mercantil constatada documentalmente, como en el caso de las anteriores, en los últimos siglos del medievo.

A la vista de estos y otros ejemplos encontrados a los que más adelante nos referiremos, nuestra investigación pretende ofrecer posibles respuestas a una serie de interrogantes planteados, teniendo en cuenta que las fuentes disponibles no siempre nos aportan una información clara. Nos preguntamos aquí en qué contextos iconográficos y manifestaciones artísticas se conservan embarcaciones de este tipo, qué casos conocemos en el territorio de estudio, si hay unas características comunes a las villas y ciudades en las que se localizan, en qué clase de templos y con qué ubicación se conservan, si es posible datar los ejemplos encontrados, qué funciones desempeñaban estas representaciones y si pueden establecerse vías de expansión artística de estos motivos iconográficos.

Para estudiar la historia del barco medieval -y, en nuestra opinión, su rica iconografía- hay que emplear tres puntos de vista: el del historiador, el del arqueólogo en el análisis de representaciones figuradas y dadas por la arqueología submarina, y el del lingüista, dado que existe todo un léxico específico ligado a los navíos ${ }^{3}$.

La iconografía medieval de embarcaciones debe ser analizarla con ciertas reservas en cuanto a los datos técnicos que pueda proporcionar, ya que los artistas a los que se les encomendaba la ejecución de estas representaciones se dedicaban preferentemente a exaltar argumentos religiosos, o a magnificar sus personajes, más que a retratar con

${ }^{3} \mathrm{CH}$. VILLAIN-GANDOSSI, "Iconographie et datations du navire médiéval", en G. DUCHET-SUCHAUX (dir.), Iconographie médiévale. Image, texte, contexte, Paris, 1990, pp. 49-73, p. 49. 
fidelidad y exactitud las naves. No obstante, aunque su identificación o interpretación sea difícil en ocasiones, el análisis de los ejemplos conservados permite hacer comparaciones en el contexto de cada época y en la tradición constructiva de unos y otros países. Partiendo de esta vocación interdisciplinar a la que se refería Villain-Gandossi, imprescindible para acometer estudios de iconografía medieval como el que ahora planteamos, debemos comenzar por el contraste de las fuentes disponibles relativas a los ejemplos de partida mencionados.
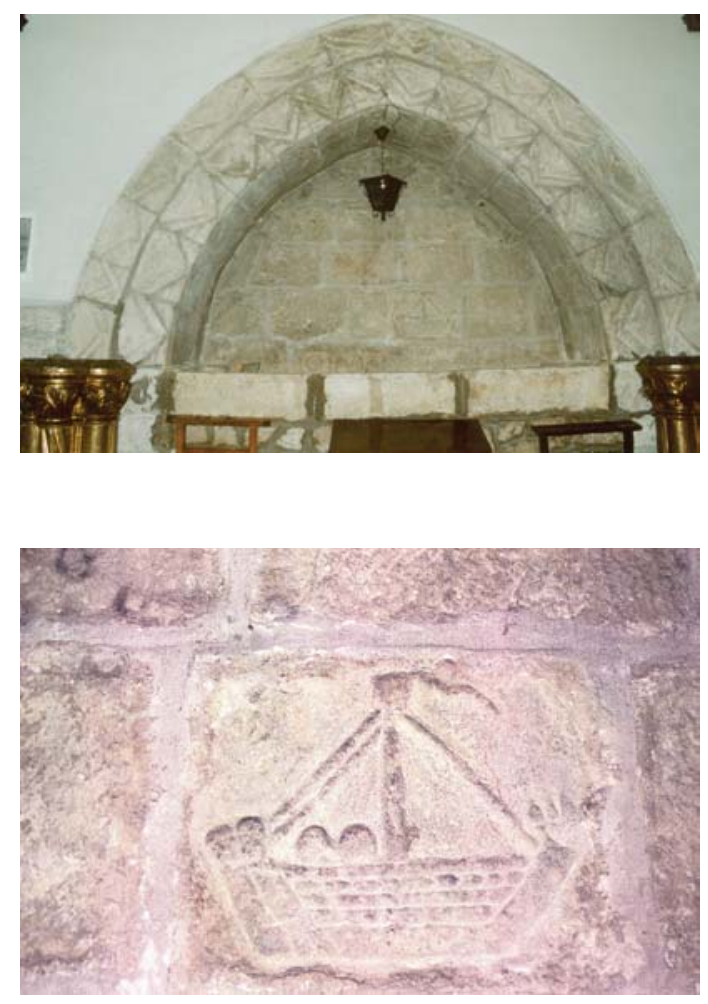

- Figs. 1 y 2.- Santa María de Llanes (Asturias). Arcosolio de nave N. y relieve de embarcación (Foto de la autora).

El primero de ellos es el barco labrado en el arcosolio interior de la nave N. de la iglesia de Santa María de Concejo de Llanes ${ }^{4}$, en uno de los sillares del lienzo del fondo (Figs. 1 y 2). Se trata de un sencillo barco de vela, con una quilla de extremos ligeramente

${ }^{4}$ Sobre esta iglesia vid. I. RUIZ DE LA PEÑA GONZÁLEZ, Arquitectura religiosa en el espacio oriental de Asturias: siglos XII-XVI, Oviedo, 2002, pp. 213-230. curvados y un mástil único rematado por lo que parece ser una bandera. En su interior se intuyen dos bultos, cuyo esquematismo no nos permite asegurar si se trata de figuras humanas o mercancías transportadas en la embarcación ${ }^{5}$.

La iglesia parroquial de Santa María de Concejo de Llanes se erigió intramuros de la villa, que aún conserva buena parte de su trazado medieval, al NW. del caserío articulado por la calle Mayor. El templo que nos ha llegado conserva su planta gótica de tres naves y cabecera poligonal, aunque con modificaciones posteriores que han alterado ligeramente $\mathrm{su}$ aspecto primitivo. La construcción de una iglesia mayor como la de Llanes respondía a las necesidades pastorales demandadas por los feligreses de las nuevas poblaciones, creadas mediante la política de repoblación urbana desarrollada en la periferia del $\mathrm{N}$. peninsular entre los siglos XII y $\mathrm{XIV}^{6}$. La erección de templos como éste es, unida al levantamiento de la cerca o muralla, una de las primeras empresas públicas acometidas por esos colectivos vecinales de las nuevas polas. Estos templos constituyen además uno de los mejores espejos del desarrollo demográfico y pujanza económica de las comunidades a las que sirven. La puebla de Llanes será, en este contexto de la baja Edad Media, la villa costera asturiana de más animada actividad portuaria y acaso la tercera en importancia de los enclaves urbanos de la región, después de Oviedo y la villa de Avilés ${ }^{7}$ Y en ella la iglesia de Santa María

\footnotetext{
${ }^{5}$ La única noticia publicada hasta el momento sobre este relieve en Ibídem, p. 223.

${ }^{6}$ J.I. RUIZ DE LA PEÑA SOLAR, Las "polas" asturianas en la Edad Media. Estudio y diplomatario, Oviedo, 1981.

7 ÍDEM, "Solidaridades profesionales en las ciudades de la corona de Castilla. Las cofradías de mareantes", en Tra economia e politica. Le corporazioni nell'Europa medievale, Pistoia, 2007, pp. 141-162; ÍDEM, "Funciones y paisajes urbanos de las villas marítimas del norte de España: Avilés (siglos XII-XV)", en Mercado inmobiliario y paisajes urbanos en el Occidente europeo (siglos XI-XV). Semana de Estudios Medievales. Estella 17-21 de julio 2006, Pamplona, 2007, pp. 691-735, especialmente pp. 697708. Sobre las reivindicaciones de las cofradías profe-
} 
de Concejo desempeñó desde su fundación la función de cabecera parroquial de la villa. El comienzo de su historia no corresponde a lo que nos ha llegado de su fábrica. Se inicia cuando Alfonso IX, rey de León, en una fecha imprecisa pero siempre antes del 24 de agosto de 1225, decide fundar la Puebla de Llanes, concediéndole el fuero muy poco tiempo después, seguramente en $1228^{8}$. En la primera fecha el rey donaba al monasterio de Santa María de Valdediós, la décima parte "totius portatici de Populatione de Lanes et unam ecclesiam in eadem populatione" $\mathrm{e}^{\prime \prime}$. Pero esa referencia a una iglesia en la Puebla de Llanes no debe confundirse con la existencia real de ese templo en fecha tan temprana, sino que se refiere sin duda a la voluntad de construcción de un primer templo parroquial en la nueva villa, como era costumbre, que sería renovado y ampliado en los siglos sucesivos en función de la demanda de la creciente y próspera población. Las noticias documentales que mencionan tanto a la propia iglesia como al abundante clero que la servía son bastante numerosas en los siglos XIII y XIV. Pero sin duda la información más rica en este último siglo es la que ofrece la Nómina Parroquial del obispo de Oviedo Gutierre de Toledo, fechada entre 1385-8910. En ella se menciona la advocación del templo -Santa María de Concejo- que nos indica que son los propios feligreses integrantes del concejo y vecinos de la villa, los

sionales de las villas cántabras en la Baja Edad Media vid. J.A. SOLÓRZANO TELECHEA, “Acción colectiva y ambiciones políticas del Común en las villas portuarias de Cantabria en la Baja Edad Media", Edad Media. Revista de Historia, vol. 14, 2013, pp. 239-257.

${ }^{8}$ M. CALLEJA PUERTA, El fuero de Llanes. Edición crítica, Oviedo, 2003; ÍDEM, "Privilegios fundacionales de las villas marítimas del Cantábrico: una perspectiva diplomática", en B. ARÍZAGA BOLUMBURU y J.A. SOLÓRZANO TELECHEA (eds.), Ciudades y villas portuarias del Atlántico en la Edad Media, Nájera, 2005, pp.147-164.

9 J.I. RUIZ DE LA PEÑA SOLAR, Las "polas" asturianas..., p. 55 .

${ }^{10}$ ÍDEM, El espacio oriental de Asturias en la Edad Media, Colección Temas de Llanes, ํo. 46, Llanes, 1989, doc. n⿳o. 17. que tienen el derecho de presentación en la provisión de los oficios eclesiásticos. Pero además, la cohesión vecinal aumenta al ser este concejo de la villa el que asume como obras públicas de su responsabilidad la edificación, ampliación y mantenimiento de esa iglesia parroquial, como se constata en otras villas asturianas y del ámbito cantábrico peninsular en la Edad Media ${ }^{11}$. En el caso de la iglesia llanisca esto queda patente en un documento expedido por los Reyes Católicos el 15 de abril de $1494^{12}$. En él se recoge la petición del concejo de la localidad de Llanes a los monarcas para poner sisa en el vino que se vendiese en ella para financiar las obras de la iglesia parroquial de Nuestra Señora, ya iniciadas e inconclusas por falta de dinero. Según recoge el documento, la interrupción de esas obras derivó de los problemas económicos de la villa al perder sus vecinos el privilegio de disfrute del salín o alfolí propio, ya que la sal era el producto fundamental para el comercio pesquero de Llanes, principal fuente de ingresos de sus pobladores ${ }^{13}$. Además de esta información el documento que analizamos nos ofrece, en fin, la valiosa fecha de referencia de las obras finales de construcción del templo de Santa María, que debieron prolongarse durante los primeros años del siglo XVI. Teniendo en cuenta esta datación debemos advertir que el arcosolio en el que se ubica el barco labrado parece anterior al resto de la fábrica gótica. Quizá se trate de un testimonio arquitectónico de ese templo primero cuya existencia se

\footnotetext{
${ }^{11}$ Destacaba la relevancia del grupo social de los feligreses en la promoción artística bajomedieval J. YARZA LUACES, "Clientes, promotores y mecenas en el arte medieval hispano", en Patronos, promotores, mecenas y clientes. Actas del VII Congreso del Comité Español del Historia del Arte, Murcia, 1992, pp. 17-47, p. 31 y siguientes.

${ }^{12}$ J.I. RUIZ DE LA PEÑA SOLAR, El espacio oriental de Asturias..., doc. no 30.

${ }^{13}$ La villa de Llanes había obtenido la disposición de alfolí para la importación, almacenamiento y distribución de sal por concesión expresa de Alfonso XI en el Ordenamiento de Burgos de 1338 (Vid. J.I. RUIZ DE LA PEÑA SOLAR y M. I. GONZÁLEZ GARCÍA, La economía salinera en la Asturias medieval, Oviedo, 1972).
} 
refleja en la documentación, que pudiera datarse en los últimos años del s. XIII o los primeros del XIV. No obstante, es posible que ni siquiera el sillar en el que fue esculpido el barco se encuentre en su lugar originario y que haya sido reutilizado trasladándolo de su ubicación original, problema que dificulta aún más la interpretación iconográfica y datación del motivo que nos ocupa. Además, como es bien sabido, la decoración de un sillar puede realizarse tiempo después de la construcción del muro en el que se inserta y la tipología del barco representado encaja, como veremos más adelante, con la de las embarcaciones empleadas a lo largo de toda la baja Edad Media en la franja costera atlántica. A este respecto, y a la vista del contexto socioeconómico en el que se erigió el templo, podemos sugerir las siguientes hipótesis sobre su interpretación iconográfica. Si el sillar se encuentra en su lugar primitivo, es posible que decorase un arcosolio de función funeraria, pudiendo pertenecer éste a un importante personaje de la villa, quizá un comerciante enriquecido que tuviera el privilegio de enterramiento en el interior el templo, gracias a alguna fundación pía. Si se tratase de una pieza reaprovechada, lo más probable -por su coincidencia de material con el empleado en el resto del templo- es que proceda de otro lugar de la propia iglesia. No obstante, no podemos descartar, dada su temática y la dilatada historia de construcción de la parroquial, que proceda de alguna edificación civil de la villa llanisca, semejante a las que aún hoy se conservan en su casco urbano medieval.

La existencia -al menos ya constatada en un documento dirigido a los Reyes Católicos en 1480- de una cofradía de mareantes en Llanes dedicada a San Nicolás, nos permite sugerir la posibilidad de que este motivo naval sea el testimonio de la contribución económica de ésta u otra cofradía relacionada con el ofiçio de la mar, para la erección de la basílica, financiada, como ya vimos, por la feligresía. Apoya esta hipótesis la mención en los estatutos e hordenanças de la cofradía mencionada de la posibilidad de hacer repar- timientos entre sus miembros para financiar sus actividades piadosas y benéfico-asistenciales ${ }^{14}$. En este sentido, es frecuente en la baja Edad Media la representación de los oficios urbanos reunidos en cofradías identificadas por ciertos símbolos, normalmente relacionados con su trabajo, fenómeno sobre el que volveremos más adelante.

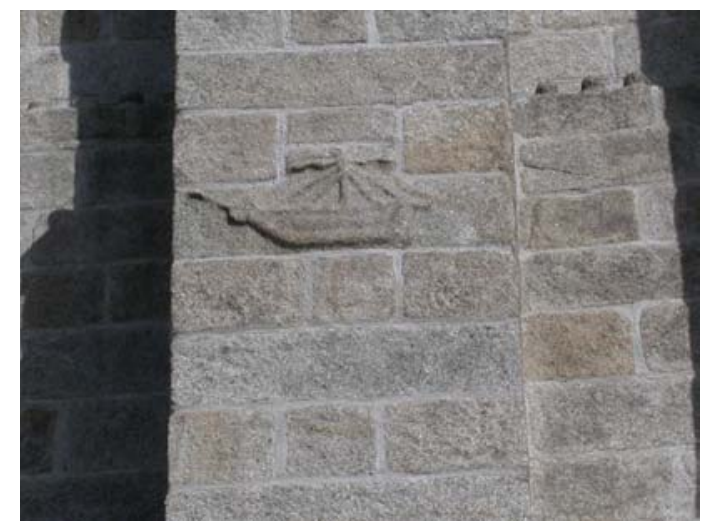

- Fig. 3.- Catedral de Oporto. Relieve de embarcación en contrafuerte de la torre N. (Foto de la autora).

El segundo ejemplo de la iconografía objeto de estudio es un relieve labrado en un contrafuerte de la torre $\mathrm{N}$. de la catedral de Oporto (Fig. 3). A una altura que no permite verlo con facilidad desde el suelo, se representa una embarcación semejante a la que encontramos en la basílica llanisca. Se trata de una nave de trazo esquemático, con quilla recta e igualmente un sólo mástil rematado por lo que parece ser una verga que se cruza en la cima de éste (Fig. 4). Se aprecia asimismo la roda de proa y el codaste. O. Lixa Filgueiras ha relacionado formalmente esta embarcación con la conservada en el museo marítimo de la ciudad alemana de Bremen, salvando la diferencia que el material granítico de la catedral de Oporto había provocado en el resultado final. El investigador resaltaba en su estudio la similitud de ambos barcos en el armazón, en la quilla recta ligada a la roda de proa que sobresale muy por encima de la borda y en el codaste de popa señalado. Iden-

${ }^{14}$ J.I. RUIZ DE LA PEÑA SOLAR, Las "polas" asturianas..., pp. 253-255. 
tificó ambos barcos con el tipo de la coca y los equiparó con las embarcaciones alemanas presentes en los sellos de las ciudades libres del Norte: Elbing, Wismar y Harderwijk ${ }^{15}$.

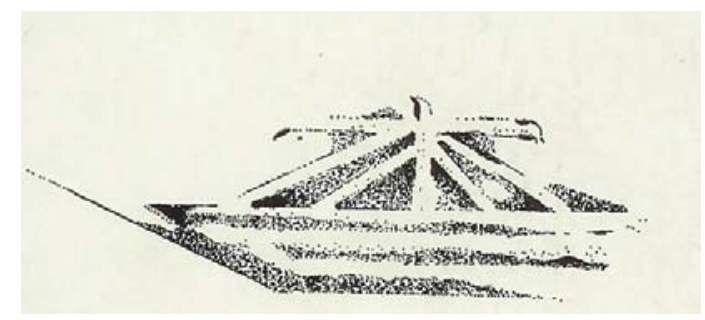

- Fig. 4.- Dibujo de nave esculpida en la fachada de la catedral de Oporto (O. LIXA FILGUEIRAS, "A nave esculpida numa Torre da sé do Porto. Ensaio de identificaçao", Arqueología, no 6, 1982, p. 112).

La catedral románica de Oporto se levanta en la parte más elevada de la ciudad histórica, y aunque en su exterior se dejan notar numerosas transformaciones acometidas a lo largo de los siglos ${ }^{16}$, lo esencial de su estructura planimétrica, alzado y materiales conserva su fábrica medieval. Los merlones de la fachada, junto con las dos torres de base románica, confieren a la catedral un aspecto defensivo. Comenzó a construirse en el último cuarto del siglo XII, al final del reinado de Alfonso Henriques (1143-1185), si bien las obras debieron continuar durante todo el siglo XIII, concluyéndose con el rey D. Dinis (1279-1325) ${ }^{17}$.

${ }^{15} \mathrm{O}$. LIXA FILGUEIRAS, "A nave esculpida numa Torre da sé do Porto. Ensaio de identificaçao", Arqueología, no 6, 1982, pp. 112-117, p. 112.

${ }^{16}$ En el Barroco se llevaron a cabo importantes intervenciones en el templo catedralicio y ya en el siglo $\mathrm{XX}$ se procedió a una restauración de la iglesia y claustro (1927-1940), casa del cabildo, sacristía y capilla de San Juan Evangelista (1942-1946). Sobre este proceso vid. M.L. BOTELHO, As transformaçoes sofridas pela Sé do Porto no século XX. A acçao da Direcçao General dos Edificios e Monumentos Nacionais (1929-1982), Trabajo de Fin del Máster en Arte, Patrimonio y Restauración, Facultad de Letras de la Universidad de Lisboa, 2004 e ÍDEM, A Sé do Porto no século XX, Lisboa, 2006. Agradezco a Álvaro Solano Fernández-Sordo estas referencias bibliográficas.

${ }^{17}$ C.A. FERREIRA DE ALMEIDA, "Primeras impressoes sobre arquitectura românica portuguesa", $R e$ -
La relación del despegue del arte románico del norte portugués desde fines del siglo XII y, sobre todo, durante la primera mitad del XIII, en relación con el lanzamiento de la red comercial y marítima en esta época es bien conocido ${ }^{18}$. Esta importante ciudad explotó el cauce de su gran vía fluvial, y el impulso desde fines del siglo XII del comercio atlántico exterior propició un gran desarrollo urbano e hizo que se convirtiera en uno de los puertos más importantes de la baja Edad Media en la Península Ibérica.

En el intento de adscripción cronológica de la embarcación tallada en la torre de la catedral de Oporto surgen de nuevo las dudas derivadas tanto de la falta de documentación, como del esquematismo de la representación. La uniformidad del aparejo del contrafuerte en el que se encuentra nos inclina a pensar en este caso que el sillar decorado mantiene su ubicación primitiva. No obstante, como advertimos al referirnos al relieve asturiano, el motivo pudo ser labrado siglos después de su construcción tardorrrománica. Sobre la posible datación de este motivo naval debemos considerar las palabras de António Cruz, recogidas por Lixa Filgueiras: "Se conoce en un documento de 1255 del archivo municipal de Porto la primera referencia expresa a una carabela e igualmente en la ciudad encontramos la que

vista da Faculdade de Letras, $1^{\text {a }}$ série, História II, 1972, pp. 65-116, ÍDEM, Historia da Arte em Portugal. O Românico, Lisboa, 2001, p. 115. Este autor propuso este edificio como cabeza de serie del románico del foco portense ("Primeras impressoes...", pp. 31-32). Otros investigadores adscriben el inicio de las obras a principios del s. XIII, prolongándose, al menos, hasta la mitad de esta centuria (P. DIAS, "O Românico duriense", en O romànico e o Douro. El Románico y el Duero, Lisboa, 1998, p. 104).

${ }^{18}$ J. MATTOSO, "O românico portugués. Interpretaçao economica e social", en José Mattoso. Obras completas. Portugal medieval. Novas interpretaçoes, Lisboa, 2002 , pp. 113-127, p. 122. Sobre el intercambio marítimo comercial y el desarrollo urbano en el país vecino en los siglos de la Baja Edad Media vid. M. FLAVIO, "The Portuguese and the Sea: Urban interaction and Exchange in the Late Middle Ages", en J.A. SOLÓRZANO TELECHEA, M. BOCHACA, A.A. AGUIAR ANDRADE (eds.), Gentes del mar en la ciudad atlántica medieval, La Rioja, 2012, pp. 275-294. 
puede ser considerada posiblemente como una de las primeras y más antiguas representaciones iconográficas de un navío. Está a considerable altura en la torre derecha del pórtico principal de la catedral de Porto, todavía en su parte románica en uno de sus contrafuertes que la refuerzan. Incrustada en el aparejo hay una piedra esculpida que data sin duda de la construcción del templo, concluido como es sabido a principios del siglo XIII"19. A este respecto Lixa añadió más prudentemente que este tipo de embarcación dominaba en el Atlántico a partir de las primeras décadas del siglo XIII ${ }^{20}$. Por nuestra parte, no podemos adherirnos a la datación que otorgaba al relieve António Cruz. Por un lado, consideramos insuficiente el testimonio impreciso de dicha mención documental, y por otra parte las características técnicas de la nave de Oporto difieren de las de las carabelas, de velas latinas y elegantes cascos de proa a veces curvados hacia atrás, bordas bajas, etc ${ }^{21}$.

A la hora de preguntarnos por la posible función de este relieve, debemos reparar, en primer lugar, en su ubicación. La representación se dispuso en un lugar importante, como es la fachada principal de toda catedral. Pero hemos de advertir que se encuentra en una posición discreta, poco accesible nítidamente por el ojo humano dada su elevada altura. Esta embarcación tipo coca nórdica fue adscrita a uno de los modelos de barcos más conocidos entre los que se usaban en la Hansa, e interpretada como un instrumento de trabajo cotidiano para los hombres de la ciudad en aquella época ${ }^{22}$. En 1297 se men-

${ }^{19}$ O. LIXA FILGUEIRAS, Op. cit., pp. 112-113.

${ }^{20}$ Ibídem, p. 113.

${ }^{21}$ F. CONTENTE DOMINGUES, "A caravela quatrocentista nas fontes da arqueologia naval portuguesa", en Actas do Congresso Internacional Bartolomeu Dias e a sua Epoca, Porto, 1988, Oporto, 1989, pp. 515-538.

${ }^{22}$ O. LIXA FILGUEIRAS, Op. cit., p. 113. Este autor reproduce algunas representaciones de la llamada coca hanseática, como la que ilustra un manuscrito de la Biblioteca Nacional de Paris y la llamada nave de Mataró, que se encuentra en el Museo Marítimo de Rotterdam, ciona en una avenencia celebrada en Lisboa entre el concejo y los maestres, a mercaderes, marineros y otras gentes que "andaban en las naves y bajeles y aloques y cocas de Fuenterrabía, San Sebastián, Bermeo, Guetaria, Castro, Laredo, Santander, Avilés y Coruña que ahora están en el puerto de dicha ciudad de Lisboa..."23. La documentación portuguesa menciona cocas en 1297 y 1370, pero no relacionadas con el tráfico comercial de Oporto. No obstante, estamos de acuerdo en admitir el carácter aleatorio de las contribuciones lingüísticas en este ámbito, y así, aunque es posible que las cocas no se hayan empleado en esta ciudad con la frecuencia con la que se utilizaban en la costa española del Cantábrico o en el golfo de Gascuña, hay que advertir que a veces se aplica un mismo término a tipos de barcos distintos, apareciendo en ocasiones indistintamente y en épocas muy diversas las menciones a barcas, barcos, carabelas, naos, etc ${ }^{24}$.

Al margen de estos matices, el comercio del puerto de Oporto con los mares del Norte está documentado desde la segunda mitad del siglo XII, así como sus escalas intermedias en los puertos de Galicia, contactos que se incrementan, desde principios del siglo XIII, con varios puertos de primera magnitud como Brujas, Londres, La Rochelle y Bayona ${ }^{25}$. En 1361 los portuenses decían

ambas fechadas en el s. XV (Ibídem, p. 114; este autor cita a A.H. DE OLIVEIRA MARQUES, Hansa e Portugal na Idade Media, Lisboa, 1959, p. 90).

${ }^{23}$ J.M. DA SILVA MARQUES, Descubrimientos portugueses. Documentos para sua historia, publicados e prefaciados por Joao Martins da Silva Marques, suplemento al Vol. I (1057-1460), Lisboa, 1944, doc. nº. 15. Sobre la actividad marítima de la villa avilesina J.I RUIZ DE LA PEÑA SOLAR, “La villa de Avilés en la Edad Media: el movimiento portuario pesquero y mercantil", en J.I RUIZ DE LA PEÑA SOLAR, M.J. SANZ FUENTES y M. CALLEJA PUERTA (coords.), Los fueros de Avilés y su época, Oviedo, 2012, pp. 13-73.

${ }^{24}$ O. LIXA FILGUEIRAS, Op. cit., pp. 115-116.

${ }^{25} \mathrm{M}$. BOCHACA, “Les gens de mer dans les villes portuaires de la France atlantique á la fin du Moyen Âge: l'exemple de Bayonne, Bordeaux et Libourne ", en J.A. SOLÓRZANO TELECHEA, M. BOCHACA, A.A. AGUIAR ANDRADE (eds.), Op.cit., pp. 45-62 . En una 
que "no tenían otro mantenimiento que la sal y el pescado" 26 , y en este extremo se pueden relacionar los medios de subsistencia de las poblaciones bajomedievales de Oporto y Llanes. A este testimonio se suma otra referencia de gran importancia: el monarca confiesa que en Oporto se concentraba el grueso de la construcción naval al testimoniar que "allí había más naves y navíos que en todo mi restante señorío". El sector mercantil en Oporto relacionado con la comercialización del pescado y con la construcción y posesión de barcos reunió algunas buenas fortunas y en el siglo XIV ya se exportaba aquel alimento. En 1369 el monarca eximía de impuestos a la venta de naos, bajeles y otros navíos que allí se construían ${ }^{27}$. Y sin duda fruto de este intercambio a mediados del siglo XIV se constatan las influencias recíprocas en los modelos y técnicas de construcción naval desde la costa noroeste portuguesa hasta Galicia, con extensiones puntuales incluso hasta Vizcaya, lugares de los que se importaban maderas, hierro, cobre, estaño, resinas y lonas, etc. ${ }^{28}$ Más allá de la costa peninsular, la fuerte demanda obligaba a comprar

de las claves de la catedral de Bayona, fechada en el siglo XIV, se labra una embarcación semejante a las de Llanes y Oporto.

${ }^{26}$ A. DE OLIVEIRA, “O giro do sal na estratégia mercantil e industrial do Porto (séculos XIV-XVII)", Revista da Faculdade de Letras-Geografía-Universidade do Porto, II Série, vol. I, 2007, pp. 139-161.

${ }^{27}$ ÍDEM, “Do Porto a Pontevedra (XIII-XVII). Os tratos marítimos no noroeste peninsular. Do Porto à Galiza e a Pontevedra (s. XIII-XVII)", en Actas do simposio de historia maritima do século XII ao XVI, Pontevedra, 2003, pp. 111-155, pp.114-117. Vid. respecto a la construcción naval en Oporto ÍDEM, O Porto. Comércio e construçao naval ao serviço da Expansao, Oporto, 1998. Este autor destaca la vital importancia de que los mercaderes -regateros y regateras- de Oporto pagaran anticipadamente el pescado que los gallegos introducían en la ciudad, existiendo ya una división de tareas en la conservación y exportación de este producto. $\mathrm{Y}$ añade que este hecho llevó a la constitución de un grupo asalariado de mano de obra gallega y de un sector mercantil en la ciudad portuguesa relacionado con la industria del pescado, que reuniría buenas fortunas.

${ }^{28}$ ÍDEM, “Do Porto a Pontevedra (XIII-XVII)...", p. embarcaciones en los mercados de Francia, Inglaterra e Irlanda. Y en este contexto de compraventa naval se ha constatado el variado origen de los propietarios, pudiendo ser éstos grandes señores laicos, pero también eclesiásticos, y asimismo, tanto particulares como los propios concejos urbanos ${ }^{29}$.

En este contexto socioeconómico atlántico, bien documentado en la ciudad de Oporto, no podemos descartar que, como apuntábamos para el caso de Llanes, alguno de estos grandes comerciantes, sin descartar a algún miembro del propio clero catedralicio, haya contribuido económicamente a las reformas góticas de la catedral portuguesa, como el claustro, comenzado a construir en 1385. Este promotor podría haber dejado constancia de su aportación al labrar el símbolo más expresivo de su dedicación profesional en el contrafuerte de la fachada del templo ${ }^{30}$.

Finalmente, en el marco de una sociedad que subsiste y se enriquece gracias a este rico comercio marítimo y fluvial, se constata en Oporto, como en Llanes, la existencia en la baja Edad Media de cofradías de marineros y comerciantes. Sin embargo, debemos advertir a este respecto que en la ciudad portuguesa las decisiones de la Cámara Municipal en materia de regulación profesional primaban sobre las cofradías, que se dedicaban más bien a las actividades caritativas y asistenciales, interviniendo su actividad en el ordenamiento religioso del litoral. Entre ellas, la de San Pedro de Miragaia acogía no sólo a los cofrades, sino también a los "caminantes, peregrinos y extranjeros de otra procedencia", como los que navegaban en dirección a Compostela, constatándose una fluida relación entre las regiones atlánticas portuenses y Galicia ${ }^{31}$. Otras cofradías de Oporto se pro-

${ }^{29}$ M.H. DA CRUZ COELLO y A.L. DE CARVALHO HOMEM, Portugal em definiçao de fronteiras. Do condado portucalense à crise do século XIV, Lisboa, 1996, p. 492.

${ }^{30}$ Sobre la iconografía de los barcos cuatrocentistas portugueses vid. F. CONTENTE DOMINGUES, Op. cit., pp. 515-538.

31 A.J. MORAIS BARROS, "Irmandades do mar (marinheiros, mercadores e Inquisiçao no Porto dos 
tegían bajo la advocación de Nuestra Señora, devoción estrechamente vinculada a las comunidades marítimas de la ciudad y su entorno, como ocurre en la villa de Llanes y en otras muchas del arco atlántico. Es posible, por lo tanto, que, como colectivo unido en sus fines piadosos, alguna de estas cofradías haya querido dejar constancia de su participación en alguna reforma o dotación de la fábrica catedralicia mediante la ubicación del relieve naval en la fachada de aquélla.

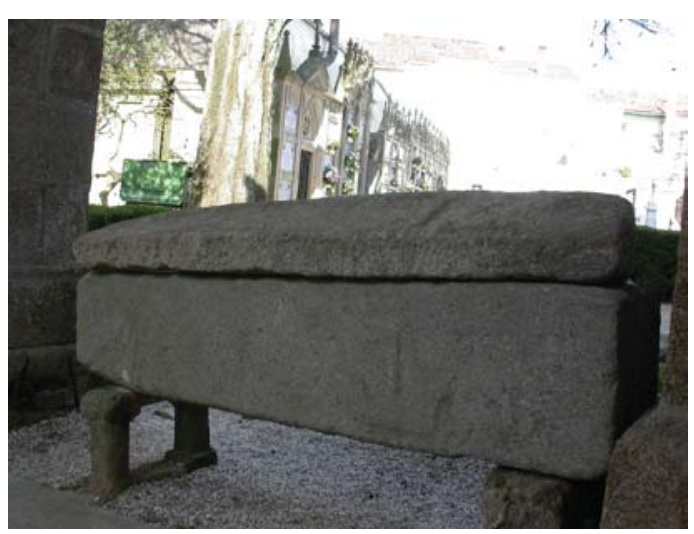

- Fig. 5.- Santa María de Noia (La Coruña). Sepulcro del pórtico W. con embarcaciones esculpidas (Foto de la autora).

En un enclave localizado geográficamente en la ruta entre Llanes y Oporto nos encontramos con el tercer ejemplo de representación naval en un relieve pétreo objeto de esta investigación (Fig. 5). Está labrado en granito en el frente de la caja de un sepulcro localizado en el pórtico de entrada de la iglesia gótica de Santa María a Nova, sita en la localidad de Noia ${ }^{32}$. Esta villa se si-

séculos XV e XVI)", en Actas do simposio de historia maritima do século XII ao XVI, Pontevedra, 2003, pp. 7394, concretamente pp. 75, 79, 80-83.

32 Sobre esta representación vid. F. ALONSO ROMERO, "Grabado de una embarcación en un sarcófago de Santa María A Nova (Noya, Galicia)", en Actes du Colloque International de Glyptographie de Cambrai, 14-1516 septembre, 1984, Braine-le-Château, 1985, pp. 150-155.

Y sobre el templo M. CHAMOSO LAMAS, "La iglesia y el cementerio de Santa María de Noya (La Coruña)", Cuadernos de Estudios Gallegos, vol. IV, 1949, pp. 251-270 y más recientemente el completo estudio de C. GONZÁLEZ PÉREZ, La iglesia y el cementerio de Santa túa en un promontorio al fondo de la ría del mismo nombre, a orillas del río Traba, en La Coruña. Pese al deterioro que presenta este relieve y a lo esquemático de su ejecución, se pueden distinguir en su observación directa dos embarcaciones: la mayor de vela, con un mástil y la quilla curvada hacia afuera, y una segunda a su lado, más sencilla, apenas apreciable (Fig. 6). La nave mayor ha sido identificada con una nao redonda de un sólo mástil con verga para vela cuadrada, un castillete de popa y probablemente otro de proa, al tipo de las embarcaciones del Atlántico. Por su parte, la pequeña embarcación situada a popa de la nao se ha calificado de batel, término aplicado al barco pequeño y ligero de silueta aplatanada ${ }^{33}$.

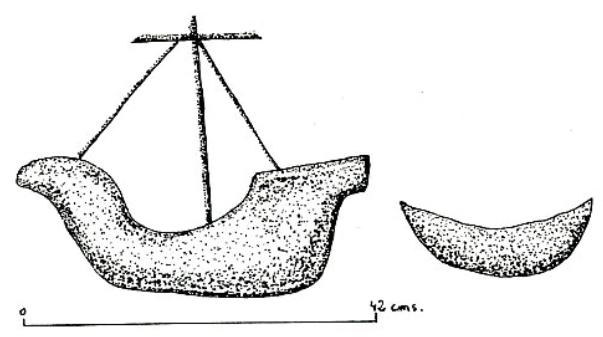

- Fig. 6.- Santa María de Noia (La Coruña). Dibujo de embarcaciones labradas en sepulcro del pórtico (W. F. ALONSO ROMERO, “Grabado de una embarcación en un sarcófago de Santa María A Nova (Noya, Galicia)", Actes du Colloque International de Glyptographie de Cambrai, 1415-16 septembre, 1984, Braine-le-Château, 1985, fig. 1, p. 153).

La iglesia de Santa María se sitúa en el corazón del cementerio, fuera de las murallas de la villa de Noia. Fue construida en

María a Nova de Noia, a Coruña, 2003, especialmente sobre la iglesia pp. 109-24 y sobre el cementerio pp. 125150.

${ }^{33}$ F. ALONSO ROMERO, Op.cit., pp. 150-155. En la costa gallega contamos con otros dos relieves navales en la colegiata de Santa María do Campo y Santa María do Azogue (Betanzos), ambas en La Coruña (ÍDEM, “A gravura dunha embarcación tipo " $\operatorname{cog}^{\prime}$ na colexiata de Santa María do Campo (A Coruña)", Brigantium, nº 3, 1982, pp. 249-253 y del mismo autor "La embarcación de Santa María do Azogue (Betanzos)", Anuario Brigantino, 1984, pp. 11-15. 
1327, como reza su inscripción fundacional ubicada sobre la portada S., sobre una antigua iglesia románica construida tras la concesión del fuero a la villa por Fernando II en $1168^{34}$, circunstancia que relaciona su historia con la referida de la iglesia de Santa María de Llanes. En su erección fue decisivo el patrocinio del arzobispo Fray Berenguel de Landoira ${ }^{35}$. Los habitantes de Noia practicaron desde antiguo las actividades pesqueras y comerciales que les facilitaba su emplazamiento privilegiado, por lo que éste será uno de los puertos más importantes de Galicia ${ }^{36}$, asentado sobre la aldea de pescadores del siglo XII, en el que se mencionan pinazas, carabelas y cuero procedente de Portugal ${ }^{37}$. La villa aparece citada como puerto de peregrinos en $1147 \mathrm{y}$ hacia el 1200 ya se documentan barcos de Noia en los puertos ingleses ${ }^{38}$. En los siglos XIV y XV la importancia demográfica y económica de la localidad aparece reflejada en la documentación y un portulano veneciano datado hacia 1400 menciona la zittá de Noia, que é porto de marea ${ }^{39}$. En estos siglos las fuentes escritas nos transmiten la existencia de una variada tipología de embarcaciones en Noia como barquos de carreto, naves, baxales o baxeles, naos, pinaças, barcos, navióo y naos, así como la llegada de barcos

${ }^{34}$ J.I. RUIZ DE LA PEÑA SOLAR, “La atracción del mar: en los orígenes de la apertura de la fachada costera Galaico-Cantábrica al mundo atlántico (1157-1252)", en Fernando III y su tiempo (1201-1252). VIII Congreso de Estudios Medievales, León, 2003, pp. 183-207, p. 194.

${ }^{35}$ C. GONZÁLEZ PÉREZ, Op.cit., pp. 51 y 70.

${ }^{36}$ Sobre la relevancia de este enclave portuario vid. F. LÓPEZ ALSINA, "La repoblación urbana costera del norte peninsular", en J.I RUIZ DE LA PEÑA SOLAR, M.J. SANZ FUENTES y M. CALLEJA PUERTA (coords.), Op.cit., pp. 131- 231.

${ }^{37}$ Sobre la actividad pesquera y comercial de la villa de Noia en la baja Edad Media C. GONZÁLEZ PÉREZ, Op.cit., pp. 41-50.

${ }^{38}$ E. FERREIRA PRIEGUE, “Las rutas marítimas y comerciales del flanco ibérico desde Galicia hasta Flandes", en Actas del Congreso del fuero de San Sebastián y su época, San Sebastián, 1981, pp. 225-230, p. 228.

${ }^{39}$ Ibídem, p. 230. y comerciantes procedentes de otras tierras, como Viana do Castelo, en el siglo $\mathrm{XV}^{40}$. Si bien en Noia escasean las noticias sobre la construcción de barcos, sabemos que se fabricaban algunos de diverso tonelaje citados en los Fueros Romanceados del siglo XV (baxeles, pinaças y naos), empleados para trasladar mercancías de transporte marítimo: cueros, unto, sebo, pescado, sal, cera, paños $^{41}$.

Por lo que respecta a la datación de las dos embarcaciones labradas en el sepulcro de la iglesia principal de la pujante villa, nos encontramos, como era de esperar, con diversas hipótesis. El primer estudio sobre el templo fechaba estos relieves en el Gótico sin más concreción ${ }^{42}$. Posteriormente otras investigaciones atribuyeron a este tipo de nao el empleo del timón de codaste, tipología generalizada a partir del siglo XIII, cuya primera representación se da en una embarcación de un capitel de la catedral de Winchester, datado en $1180^{43}$. Este autor, no obstante, retrasa la datación del ejemplo gallego hasta el siglo XIV.

Una vez vista la tipología y el contexto socioeconómico en el que se inscribe este tercer ejemplo iconográfico, debemos profundizar en las posibles motivaciones para su plasmación plástica. A diferencia de los otros dos casos, debemos tener en cuenta en el que nos ocupa el hecho de que se labre en la caja de un sepulcro. Esta particularidad individualiza a su comitente respecto a los ejemplos anteriores, en los que no podemos decantarnos por una

${ }^{40}$ C. GONZÁLEZ PÉREZ, Op.cit., pp. 58 y 68. Un completo estudio sobre la tipología de las naves medievales en el territorio de estudio en E. FERREIRA PRIEGUE, Galicia en el comercio marítimo medieval, A Coruña, 1988, pp. 219 y siguientes.

${ }^{41} \mathrm{X}$. TORRES REINO, "Laudas profesionales con marcas de marinería en el cementerio de Santa María a Nova de Noia", en Actas du VII Congréss du Glyptographie de Rochefort-sur-Mer, T. I, Paris, 1991, pp. 225-232, p. 225.

${ }^{42}$ M. CHAMOSO LAMAS, Op. cit., p. 262.

${ }^{43}$ F. ALONSO ROMERO, Op.cit., p. 152. 
iniciativa personal o colectiva. Como en los importantes puertos de Llanes y Oporto, en Noia existían agrupaciones profesionales ligadas a los variados oficios de la villa: artesanos para construir y reparar barcos (carpinteros de ribera), envasadores de los productos toneleros, herreros, zapateros, tejedores, etc. Además de velar por la salvación eterna estas cofradías defendían su patrimonio terrenal controlando a los artesanos foráneos y regulando los precios entre otras atribuciones ${ }^{44}$. Pero en 1253 Alfonso $X$ ordena la disolución de todas estas agrupaciones de la Tierra de Santiago, excepto aquellas cuyos fines fuesen estrictamente piadosos ${ }^{45}$.

En todo caso, la existencia de un rico museo de lápidas gremiales labradas con sus marcas en el templo ${ }^{46}$ testimonia el interés de los grupos profesionales de la villa por diferenciarse en el recinto funerario. Se ha sugerido que en época medieval posiblemente cada cofradía contaba con un terreno propio en el cementerio, jerarquizándose estos espacios en función de la consideración social de cada oficio ${ }^{47}$. A este respecto y en relación con el sepulcro que nos ocupa, no podemos asegurar que su privilegiada ubicación actual bajo el pórtico de acceso principal al templo sea la originaria. Pero las proporciones y la calidad del enterramiento nos sugieren que el destinatario del mismo pudo haber sido uno de los comerciantes o burgueses enriquecidos con el negocio del transporte marítimo o la construcción de barcos de Noia, cuya intención de distinguirse del resto de los feligreses allí enterrados queda patente. En efecto, en el conjunto de laudas conservadas se encuentran algunas con signos propios de

${ }^{44}$ J.A. SOLÓRZANO TELECHEA, "Protéger et contrôler la présence et les activités des étrangers dans les villes portuaires du Nord de la Couronne de Castille au Moyen Âge", Annales de Bretagne, vol. 117, 2010, pp. 209-222.

\footnotetext{
${ }^{45}$ C. GONZÁLEZ PÉREZ, Op.cit., p. 49.

${ }^{46}$ Ibídem, pp. 143-224.

${ }^{47}$ Ibídem, p. 130.
}

los oficios relacionados con la actividad marítima, tales como anclas, escuadras y compases, ondas marinas, conchas de vieiras, arpones, etc. ${ }^{48}$, presentes también en otras villas atlánticas. Se conocen algunas marcas propias de los marineros del N. de Portugal (Póvoa de Varzim), estudiadas en 1932 por António dos Santos Graça. También están presentes en el S. de Galicia (A Guarda, Baiona, Bouzas, Vigo, Cangas de Morrazo, etc.), tratadas por Antón Ferreira Lorenzo ${ }^{49}$. Por lo que respecta a la cronología atribuida a las laudas de Noia, éstas no se suelen datar más allá de las primeras décadas del siglo XIV, cuando se construye la iglesia y, como vimos, después de la supresión de las competencias reguladoras profesionales de las cofradías, que pasarán a tener únicamente fines devocionales. Pertenecían éstas tanto a marineros (navegación de altura), como a mareantes (hombres de ribera, muchos de ellos mercaderes y propietarios de barcos, como posiblemente el caso que nos ocupa) y pescadores sin barco propio $^{50}$. Una hipótesis del objetivo de esta representación es la búsqueda de la protección divina para las naves del patrocinador o para él mismo, dado que era frecuente el encargo del sepulcro bastante tiempo antes del fallecimiento del destinatario ${ }^{51}$. En la iglesia gótica de Santa María del Mar (Barcelona) encontramos algunas sepulturas de pavimento en las que se labran ricas embarcaciones (Fig. 7), cuyos patrocinadores sin duda procedían del mismo ámbito profesional y tenían la misma intención que el propietario noiés ${ }^{52}$.

${ }^{48}$ X. TORRES REINO, Op. cit., pp. 226-227.

${ }^{49}$ C. GONZÁLEZ PÉREZ, Op.cit., pp. 154 y 156-157.

${ }^{50}$ Ibídem, pp.185-190.

${ }^{51}$ F. ALONSO ROMERO, Op.cit., p. 151.

52 Sobre el puerto medieval de Barcelona a partir de los hallazgos arqueológicos recientes vid. M. SOBERÓN RODRÍGUEZ, "El port baixmedieval de la ciutat de Barcelona: una visió des l'arqueologia. L'escullera de 1477 i la troballa d'un vaixell tinglat", Quarhis, época II, no 6, 2010, pp. 134-163. 


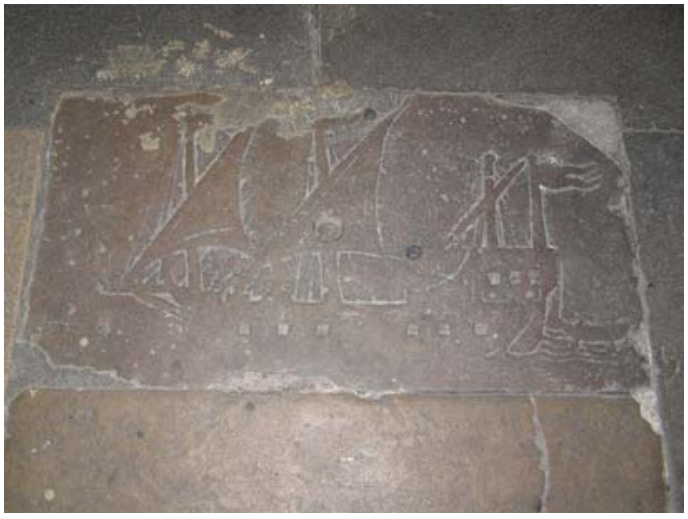

- Fig. 7.- Santa María del Mar (Barcelona). Relieve de embarcación en sepultura del interior. (Foto de la autora).

Para finalizar el análisis de este tercer ejemplo debemos mencionar que es muy posible que desde el siglo XIV los marineros y mareantes de Noia se agrupasen en la cofradía de San Nicolás -como en la villa de Llanes- y los pescadores en la del Corpo Santo, denominación que se atribuía en Galicia a las reliquias de San Telmo, patrón de la diócesis de Tuy-Vigo, venerado también, por otra parte, en la ciudad de Oporto ${ }^{53}$. Por todo ello debemos concluir que las circunstancias socioeconómicas y devocionales en las que se contextualizan las embarcaciones de Noia coinciden básicamente con las que rodean las representaciones asturiana y portuguesa.

En las postrimerías de la Edad Media, el arco atlántico nos ofrece aún más ejemplos de embarcaciones esculpidas, tanto en edificios de culto como residenciales. El afamado prestigio de los astilleros del Cantábrico impulsa a los monarcas del siglo XVI a emitir sendas pragmáticas que prohibían participar en la Carrera de Indias a cualquier barco que no hubiera sido fabricado en el Cantábrico ${ }^{54}$. Prueba de la prosperidad de esta industria son testimonios iconográficos como el relieve de una embarcación con un motivo jaco-

${ }^{53}$ C. GONZÁLEZ PÉREZ, Op.cit., pp. 185-186.

${ }^{54}$ J.L. CASADO SOTO, "Aproximación a la tipología naval cantábrica en la primera mitad del siglo XVI", Itsas. Revista de Estudios Marítimos del Pais Vasco, no 2, 1998, pp. 169-191, p. 170. beo, fechado hacia 1500 en la iglesia de San Andrés de Zaldíbar (Vizcaya). Por último, si bien en la arquitectura residencial medieval de la zona estudiada se conservan menos ejemplos, podemos citar los relieves esquemáticos -pero sumamente interesantes- de una chalupa ballenera en un dintel de una casa de la calle Azara en Zarautz (circa. 151020) y el labrado en un mainel de una ventana geminada en la calle Almirante Oa en Orio (circa. 1510-30), que representa una pinaza o galeón de pesca ${ }^{55}$. En la costa portuguesa se conserva, en fin, un barco esculpido en la residencia de Pero Galego, en la rua da Parenta (Viana do Castelo).

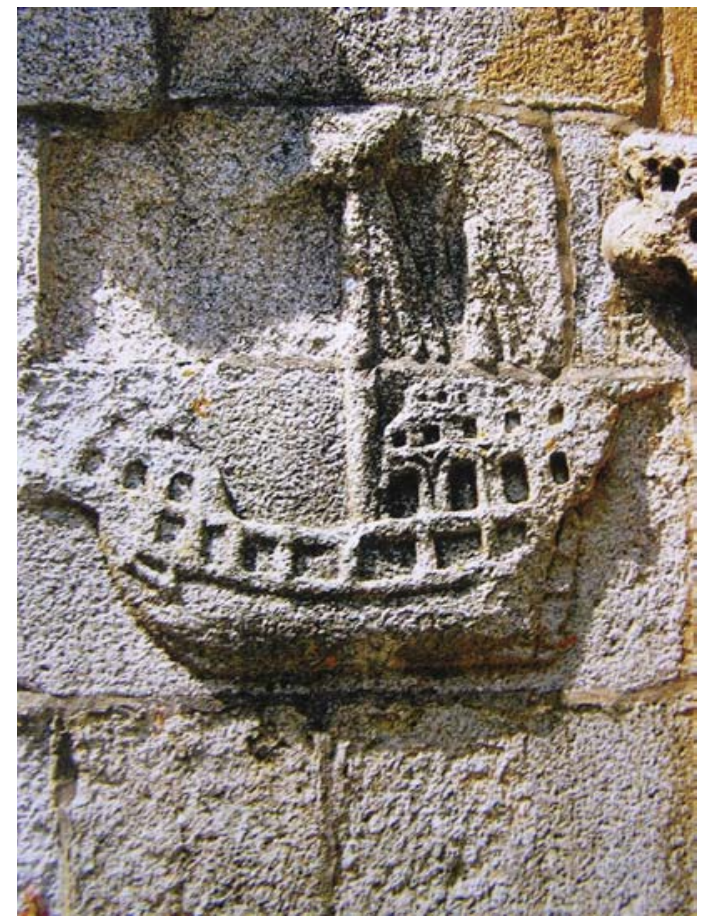

- Fig. 8.- Iglesia de Saint Nonna (ca. 1508), Penmarch (Bretaña). Relieve de embarcación del pórtico (Foto de la autora).

Si bien ya en territorio francés, para concluir este repaso a los ejemplos tardomedievales en soporte escultórico debemos mencionar los relieves de embarcaciones conservados en el pórtico de la fachada W. de la iglesia de Saint Nonna (ca. 1508), ubicada en una destacada villa portuaria de la

${ }^{55}$ Ibídem, pp. 173-174. 
costa del Finisterre de Bretaña denominada Penmarch (Fig. 8). En este caso, la erección del templo se debe a las donaciones de los armadores de la villa, hecho que nos sitúa en el mismo contexto de los ejemplos que estamos viendo en las costas portuguesas, gallegas y asturianas, con las que está documentado el intercambio comercial en la baja Edad Media $^{56}$. Igualmente, en una de las claves de la catedral de Bayona fechada en el siglo XIV se labra con gran detalle una embarcación semejante a las de Llanes y Oporto, que se ha calificado como una de las primeras representaciones de barco con timón de codaste ${ }^{57}$.

El análisis, a través de las fuentes disponibles, de los relieves de las embarcaciones esculpidas en Llanes, Oporto y Noia, a los que se suman otros casos similares del territorio de referencia, nos ha permitido adelantar unas conclusiones parciales sobre la posible tipología, cronología y función de estas representaciones concretas. Pero para avanzar un paso más en nuestra investigación, debemos comparar estos ejemplos iconográficos con otras representaciones de naves de diversos tipos conservadas en el arco atlántico. Éstas no sólo se ligan a un soporte escultórico, sino a otras manifestaciones artísticas como la miniatura, la pintura mural, la sigilografía, la numismática y los textiles. La atención a estos otros ejemplos contribuye a precisar los motivos que movieron a los hombres medievales a incorporar estas embarcaciones, con las que sin duda se identificaban, a sus edificios de culto, viviendas y construcciones defensivas, pero también a los sellos distintivos de sus villas y ciudades, y a otros objetos cotidianos transmisores de imágenes, como las monedas.

Como es bien sabido, en la iconografía religiosa es frecuente la evocación de la vida de los personajes bíblicos y de los santos mediante sus travesías marítimas, reales o sim-

${ }^{56} \mathrm{H}$. TOUCHARD, Le commerce atlantique maritime breton a la fin du Moyen Age, París, 1967.

${ }^{57}$ J. LÓPEZ, “Nuestros barcos", Bertan, 23, 2009 con fotografía. Consultado el 10 de mayo de 2014. URL: http://bertan.gipuzkoakultura.net/23/caste/8.php. bólicas, recogidas en las fuentes textuales ${ }^{58}$, y que incluyen como elemento primordial -o evocador del pasaje de forma sintética- la embarcación en la que se realizó el viaje $\mathrm{e}^{59}$. En la costa atlántica de la Península Ibérica contamos con algunos ejemplos iconográficos especialmente curiosos, por incorporar estos temas de la traslatio santa en barco a objetos profanos, pero ligados, a través de su iconografía, al culto local. Uno de ellos es la representación de la traslación del Apóstol Santiago en barco en el reverso de una moneda acuñada en el reinado de Fernando II de León (1157-1188), hallada en la parroquia de San Vicente (Pontevedra) ${ }^{60}$. La misma representación aparece labrada en el tímpano de la portada de Santiago de Cereixo (La Coruña).

${ }^{58}$ CH. VILLAIN-GANDOSSI, Op.cit., p. 51.

${ }^{59}$ Entre los ejemplos más significativos presentes ya en el arte paleocristiano se encuentran los pasajes bíblicos del profeta Jonás y la historia del arca de Noé. Y en el arte románico el pasaje de la Pesca milagrosa, con numerosos ejemplos iconográficos -fundamentalmente esculpidos- en los que las barcas y las redes adquieren igual relevancia que los protagonistas de la narración (vid. con carácter general para el reino de Castilla J.L. CASADO SOTO, "Arquitectura naval atlántica en los sellos concejiles medievales españoles", en Navigare necesse est. Estudios de Historia Marítima en honor de Lola Higueras, Gijón, 2008, pp. 109-141, pp. 113-116 y sobre los barcos representados en las miniaturas de las Cantigas de Alfonso X el Sabio J. GUERRERO LOVILLO, Las Cantigas, estudios arqueológico de sus miniaturas, Madrid, 1949, cap. dedicado a la arquitectura naval pp. 324-339; la núm. XXXVI representa una nao cantábrica (1256-63). Es el caso de la navegación milagrosa de San Regolo, San Cerbone y otros santos evangelizadores de Volterra labrados en un friso en la portada de la fachada principal de la catedral de Santa María y San Cerbone de Massa Maritima (Toscana italiana). Se ha fechado este relieve hacia el año 1200, y la escena se relaciona con la representación del viaje de San Giminiano a Constantinopla, esculpida en el arquitrabe de la Puerta de los Príncipes de la catedral de Módena, muy anterior (1115), pero seguramente conocida para el escultor de la primera (G. TIGLER, Toscana romanica, Milano, 2006, pp. 89-96). Finalmente, no hay que olvidar que el barco es el atributo de numerosos santos, como San Nicolás de Bari o Santa Úrsula.

${ }^{60} \mathrm{~J}$. CARRO OTERO, "Moneda del rey D. Fernando II de Galicia-León y ceca compostelana, con el tema de la Traslación del cuerpo del Apóstol Santiago (1157-1188)", Compostellanum, vol. XXXII, nº. 3-4, 1987, pp. 575-592. 
Por otra parte, en el sello de Lisboa se evoca el traslado de San Vicente a esta ciudad mediante la representación de una embarcación de un mástil con la vela recogida, guiada por dos cuervos ${ }^{61}$. No obstante, como ya advertimos más arriba, el grado de fidelidad de estas representaciones en relación a los tipos reales de barcos vigentes en la época en que se realizaron es bastante escaso, tanto por la prioridad otorgada al símbolo y a la historia como por el propio marco iconográfico. El barco de la moneda curva su casco forzadamente para adaptarse a la forma redonda de aquélla, distorsionando las características técnicas de las naves, lo que dificulta sobremanera la identificación de la tipología concreta que, por otra parte, no debía constituir una prioridad para el orfebre de la ceca.

En las representaciones profanas de naves la ausencia de un pasaje sagrado que transmitir al espectador las acerca, en algunas ocasiones, algo más fielmente, a los tipos de barcos que se empleaban tanto en la pesca y el comercio marítimo, como en las batallas navales. Precisamente en este contexto iconográfico político-bélico se inscribe uno de los mejores documentos artísticos medievales para el estudio de la construcción naval y de los modelos de embarcaciones atlánticas. Se trata del tapiz o bordado de Bayeux (10661082), que describe la conquista de Inglaterra por los normandos, en el que se documenta con todo lujo de detalles el proceso técnico de construcción de los barcos, así como su ornamentación y piezas simbólicas, incluyen-

\footnotetext{
${ }^{61}$ A. AGUIAR ANDRADE, “La dimensión urbana de un espacio atlántico: Lisboa", en Mercado inmobiliario y paisajes urbanos en el Occidente europeo (siglos XI-XV). Semana de Estudios Medievales. Estella 17-21 de julio 2006, Pamplona, 2007, pp. 347-375, pp. 359-360, lámina 60, y L. KRUS, "San Vicente e o mar: das relíquias às moedas", en Passado, memória e poder na sociedade medieval portuguesa. Estudos, Redondo, 1994, pp. 145-146. Se representa este motivo del sello de Lisboa en una inscripción pétrea conmemorativa de la ejecución del Chafariz del Largo do Andaluz de la capital portuguesa, fechada en 1336 (M.J. BARROCA, Epigrafía medieval portuguesa (862-1422), vols. II y III. Anexos, índices, bibliografia e estampas, Oporto, 2000, vol. II, tomo 2, no 586, pp. 1.5741.578 y vol. III, Estampa CLXXVIII, no 1 y no 2 , p. 479).
}

do inscripciones bordadas referidas a cada escena $^{62}$. En este caso la ventaja respecto a otras fuentes iconográficas es la posibilidad de contrastar este bordado documentalmente con el texto que narra la preparación de la expedición: la Gesta Guillelmi escrita por Guillermo de Poitiers ${ }^{63}$. Además, la comparación entre los barcos descubiertos en los países nórdicos, como los de Skudelev (Dinamarca) y los representados en el bordado permiten constatar la fidelidad arqueológica de estos últimos, ya que en ambos casos se destaca la forma afilada del estrave y del codaste ${ }^{64}$.

Además de los textiles, la pintura medieval nos ofrece numerosas representaciones de barcos. Por un lado la miniatura bajomedieval profana incluye imágenes de naves en las ilustraciones de las crónicas, anales, relatos de cruzadas, canciones de gesta, novelas, así como en la iluminación de los textos de literatura didáctica, alegórica, bestiarios y tratados científicos ${ }^{65}$.

Por otro lado, la pintura mural nos ofrece algunas imágenes de embarcaciones pintadas al fresco, algunas de las cuales parecen inscribirse en el campo de lo profano. En el ámbito geográfico de nuestra investigación se conserva una representación de dos barcos -uno principal y lo que parece otra pequeña nave auxiliar-, pintada al fresco en el interior de la cabecera de la ermita del hospital de San Lázaro de Abaño, en San Vicente de la Barquera (Fig. 9), villa cantábrica muy cercana a Llanes y con una gran pujanza marítima apoyada por su cofradía de mareantes ${ }^{66}$. Si bien la fundación se documenta

${ }^{62}$ Una de ellas precisamente se refiere a la construcción de las naves: "HIC WILLELM DUX IUSSIT NAVES EDIFICARE"

${ }^{63}$ P. BOUET, B. LEVY, F. NEVEUX, (eds.), La tapisserie de Bayeux: l'art de broder l'Histoire. Actes du Colloque de Cerisy-la-Salle (1999), Caen, 2004.

${ }^{64}$ A.M. FLAMBARD, "La tapisserie de Bayeux et l'archéologie", en Ibídem, pp. 261-288, pp. 280-281.

${ }^{65}$ CH. VILLAIN-GANDOSSI, Op.cit., pp. 52-53 e ÍDEM, Le navire médiéval à travers les miniatures, Paris, 1985.

${ }^{66}$ J.A. SOLÓRZANO TELECHEA, "Las ordenanzas de la Cofradía de Mareantes de San Vicente de la Bar- 
ya en 1232, la fábrica actual y la tipología de la embarcación principal corresponden a los siglos XIV ó XV ${ }^{67}$. Ésta, de un solo mástil y vela cuadrada, se acerca formalmente a las representaciones de Llanes y Oporto, lo que nos ayuda a aproximar la datación de todas ellas a fines del Gótico.

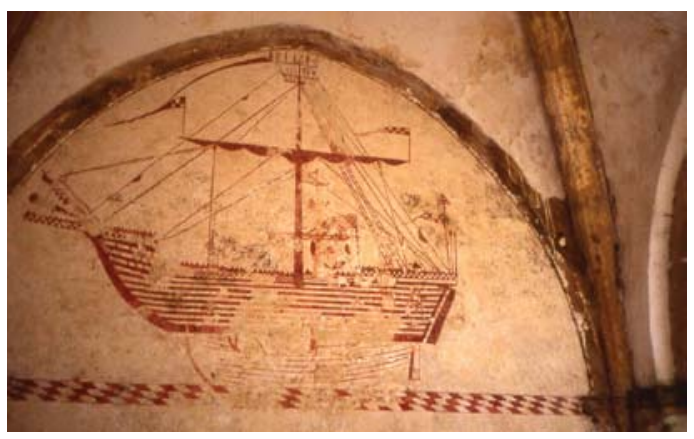

- Fig 9.- Ermita de la malatería de Abaño. San Vicente de la Barquera (Cantabria). Embarcación pintada en el interior del muro S. de la cabecera (Foto de la autora).

Junto a los ya mencionados, uno de los soportes iconográficos más ricos en la costa atlántica peninsular con representaciones profanas de naves bajomedievales son los sellos $^{68}$ de las principales villas portuarias marítimas $^{69}$. Actualmente se conservan 18

quera: un ejemplo temprano de institución para la acción colectiva en la Costa Cantábrica en la Edad Media", Anuario de Historia del Derecho español, vol. 81, 2011, pp. 1.029-1.050.

${ }^{67}$ E. CAMPUZANO RUIZ, El Gótico en Cantabria, Santander, 1985, p. 260.

${ }^{68}$ Aludía recientemente a la especificidad de la imagen sigilar sobre el resto de las medievales, por extenderse el uso de los sellos a todas las categorías sociales, M. PASTOUREAU, "Les sceaux et la fonction sociale des images", en J. LE GOFF y J.C. SCHMITT (eds.), Diccionario razonado del occidente medieval, Madrid, 2003, pp. 275-308. En concreto destacaba la importancia de las representaciones de naves en tres dimensiones de los sellos y medallas S. ROSE, The medieval sea, London, 2007, p.13.

${ }^{69}$ J.L. CASADO SOTO, Op.cit., pp. 109-141, J.M. DE FRANCISCO OLMOS y F. NOVOA PORTELA, La colección sigilográfica del Museo Nacional de Artes Decorativas, Madrid, 2002, pp. 100-104,117, 209-210 y 217; para Portugal G. LANCASSTRE E TÁVOARA, O estudo da sigilografia portuguesa, Lisboa, 1983. sellos usados en el Atlántico castellano durante el siglo XIII y comienzos del XIV, con simbología marina: peces, ballenas y barcos, combinados de forma diferente ${ }^{70}$ (Figs. $10 \mathrm{y}$ 11). Entre ellos se encuentran los de Avilés y Luarca (Asturias), San Vicente de la Barquera y Santander (Cantabria), los de los concejos de Bermeo ${ }^{71}$, San Sebastián y Fuenterrabía, los tres vascos y datados en $1297^{72}$, así como los sellos con naos cantábricas de algunos burgos de Navarra. En estos sellos concejiles se reflejaban los elementos de los que las comunidades urbanas estaban más orgullosas, hasta el punto de instituirlos en emblemas o símbolos heráldicos ${ }^{73}$. Por lo tanto, la función de estas imágenes sintéticas es clara: destacar la pujanza de la economía pesquera y/o comercial de estas localidades, que en algunas ocasiones coincidía con la relevancia de sus astilleros, que exportaban naves demandadas por otros puertos faltos de construcciones propias. Todos ellos datan del siglo XIII y por lo tanto son muy útiles como referencia de los tipos vigentes en el Atlántico en la baja Edad Media, salvando el margen de distorsión plástica al adaptar la estructura de sus cascos a la forma del soporte. Recientemente se ha indicado la posibilidad de conocer, a través de estas imágenes sigilares, la especialización económica en función del tipo de embarcación. La iconografía distingue los tres tipos básicos empleados en la Edad Media, a saber de mayor a menor: nao, barca y pinaza ballenera. La nao era el tipo de buque más frecuente entre los de altura a fines del siglo XIII, tal como se manifiesta en el inventario de la flota presente en Lisboa en 1297, en el que el

${ }^{70}$ J.L. CASADO SOTO, Op.cit., p. 119, lámina con todos ellos reproducidos a la misma escala en p. $137 \mathrm{y}$ catálogo en pp. 120-136.

${ }^{71}$ A.M. RIVERA MEDINA, “Paisaje naval, construcción y agentes sociales en Vizcaya: desde el medioevo a la modernidad", Itsas. Revista de Estudios Marítimos del Pais Vasco, no 2, 1998, pp. 49-92, p. 51.

${ }^{72}$ X. ALBERDI LONBIDE y A. ARAGÓN RUANO, "La construcción naval en el País Vasco durante la Edad Media", Itsas. Revista de Estudios Marítimos del Pais Vasco, no 2, 1998, pp. 13-33, p. 32.

${ }^{73}$ J.L. CASADO SOTO, Op.cit., pp. 113-114. 
$64 \%$ de los barcos cantábricos eran naos, con vela cuadrada y forro de tingladillo ${ }^{74}$.
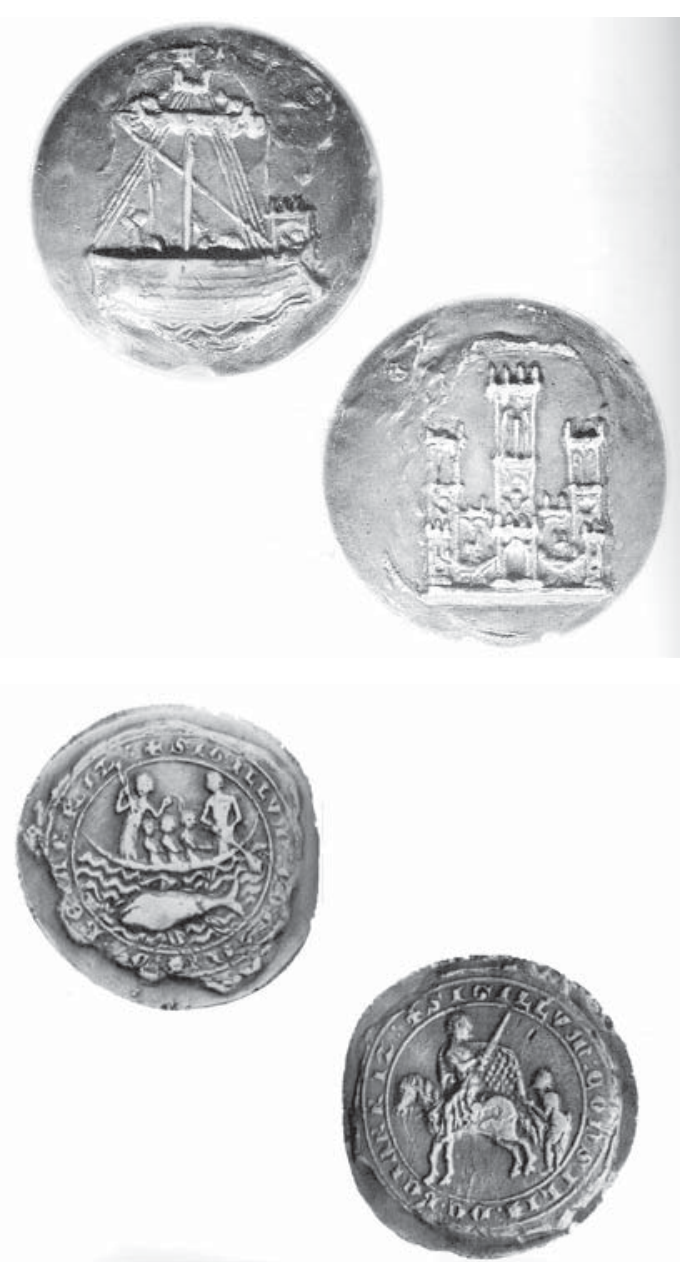

- Figs. 10 y 11.- Representaciones de naves en los sellos concejiles de Santander y Biarritz (J.M. DE FRANCISCO OLMOS y F. NOVOA PORTELA, La colección sigilográfica del Museo Nacional de Artes Decorativas, Madrid, 2002, pp. 210 y 217).

Otro interesante campo de representación naval son los grafitos que aparecen tanto en el medio rural como urbano y tanto sobre edificios privados como públicos, civiles, militares, religiosos, etc. (Fig. 12), si bien en las iglesias son más numerosos ${ }^{75}$. Pese a su trazado extremadamente esquemático y rápido, y a

${ }^{74}$ Ibídem, pp. 139-140.

${ }^{75}$ L. BUCHERIE, "Panorama des graffiti maritimes des Côtes du Ponant", en Actes du VIléme Colloque International de glyptographie de Rochefort-sur-Mer, T. II, París, 1991, pp. 109-145. su escasa calidad artística, constituyen una valiosa fuente de documentación para la historia del navío. Grabados por gentes de mar, gentes de río, o simples espectadores, estas representaciones se tomaban generalmente del natural y carecen de anacronismos, revelando detalles técnicos mucho más fieles a los modelos reales que los del resto de soportes iconográficos, aunque en general se muestren de perfil ${ }^{76}$. En los países del norte de Europa se conservan abundantes grafitos navales fechados en la alta Edad Media, como el de Häggeby (Museo de Estocolmo, ss. V-VI), y el de Jalrshof (Escocia, ss. IX-X). Crónicas y sagas narran las historias de los viajeros escandinavos, en las que la nave es el medio esencial para sus viajes en la vida terrena, y se convierte también en el vehículo para conseguir la ultraterrena ${ }^{77}$.

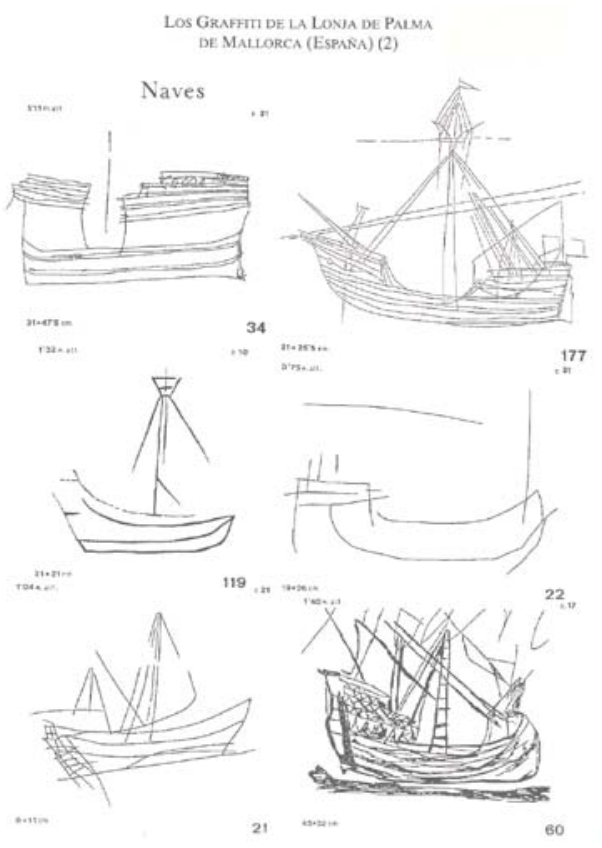

- Fig. 12.- Grafitos de embarcaciones de la lonja de Palma de Mallorca (E. GONZÁLEZ GONZALO, "Los graffiti de la lonja de Palma de Ma-

${ }^{76} \mathrm{CH}$. VILLAIN-GANDOSSI, Op.cit., p. 55. A ello contribuye a buen seguro la total libertad del campo de grabado.

77 T. PÀROLI, "L'acqua come elemento tra vita e morte nella cultura germanica medievale", en L'acqua nei secoli altomedievali, Atti delle settimane LV. Tomo secondo. Spoleto, 12-17 aprile 2007, T. II, Spoleto, 2008, pp. 1.237-1.322, pp. 1.295-1.296, figs. 7a y 7b, Lám. IX. 
llorca (España) (2)", en Actes du VIléme Colloque International de glyptographie de Rochefort-surMer, T. I, París, 1991, p. 128).

Sin embargo, su número aumenta desde el siglo XIII hasta el XVI y en Francia abundan sobre todo en la franja costera atlántica. En territorio hispano, sin embargo, destaca su abundancia en relevantes edificios civiles de la ciudad de Mallorca, como la lonja y la Torre de Santa Ponça, si bien estos últimos ya fechados en el siglo XVII ${ }^{78}$. Asímismo, en el castillo de Olivenza, sito en la provincia de Badajoz, muy próximo a la frontera portuguesa, se conserva un grafito de una coca atlántica ibérica fechada a principios del siglo XIV, muy semejante a las analizadas en el presente estudio y que constituye una excepción en el conjunto de ejemplos estudiados por su localización alejada de la costa ${ }^{79}$.

El contraste de las fuentes iconográficas, arqueológicas y textuales disponibles sobre la iconografía naval en la fachada costera atlántica de la Península Ibérica, nos permite responder a algunas de las cuestiones que nos impulsaron a desarrollar esta investigación.

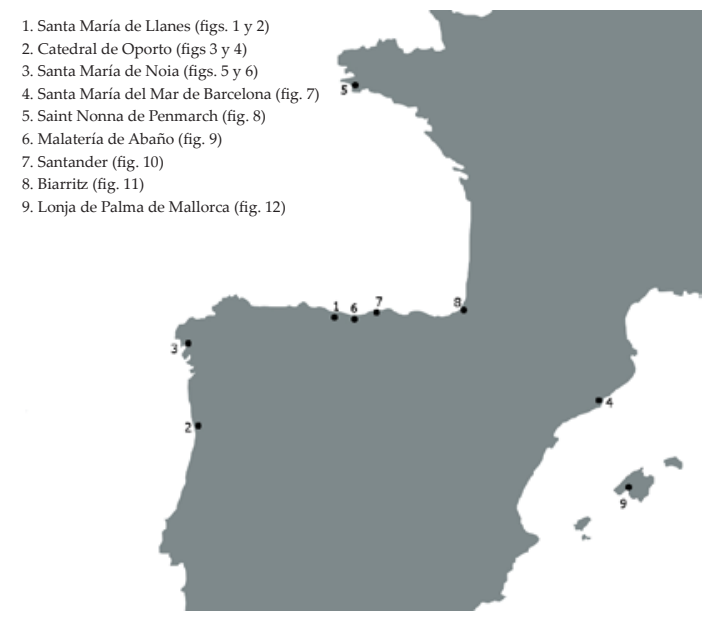

- Fig. 13.- Mapa de localización de los ejemplos reproducidos en las fotografías.

${ }^{78}$ E. GONZÁLEZ GONZALO, "Los graffiti de la lonja de Palma de Mallorca (España) (2)" y "Los graffiti navales de la torre de Santa Ponça (Mallorca)", en Actes du VIIéme Colloque International de glyptographie de Rochefort-sur-Mer, T. I, Paris, 1991, pp. 121-133 y 135-156.

${ }^{79}$ J.L. CASADO SOTO, Op.cit., p. 115.
A la vista de los ejemplos encontrados, podemos constatar la aparición de estos motivos iconográficos en las villas $\mathrm{y}$ ciudades costeras de destacada actividad económica en los sectores de la pesca, construcción naval y comercio atlántico, hecho del que derivan unas semejantes pautas de relación social y de expresión devocional de sus habitantes (Fig. 13).

Respecto a la naturaleza de los edificios en los que se conservan, no se puede establecer, sin embargo, una constante. La iglesia de Llanes es una parroquial financiada por la propia feligresía, el ejemplo portugués se encuentra en una catedral y la iglesia de Santa María de Noia tiene patrocinio episcopal, si bien asumió igualmente funciones parroquiales. Si atendemos a otros casos citados, la embarcación pintada en Abaño (Cantabria) se adscribe a la ermita de un hospital y encontramos otros casos en torres defensivas, faros, viviendas y sellos de identidad de las villas portuarias atlánticas. De esta diversidad debemos concluir que la representación de embarcaciones no depende de la envergadura ni función de la iglesia o edificio, sino más bien de su localización costera, determinante de las fuentes de subsistencia de la población que patrocina, demanda y se identifica con este símbolo de su entorno cotidiano ligado al mar. Como quedó reflejado a lo largo del trabajo, tampoco podemos mencionar constantes respecto a la ubicación de esta iconografía en los edificios mencionados, que aparecen en las zonas más diversas de los mismos: arcosolio interior, contrafuerte de fachada, sepulcro, ábside, etc.

En general no hay consenso por parte de los historiadores y arqueólogos a la hora de identificar las distintas representaciones de barcos medievales con tipos concretos. Los documentos son poco explícitos y comportan numerosos sinónimos, como coca, nave, nao y pinaza entre otros. No obstante, los tres ejemplos aquí analizados se asemejan en sus características fundamentales como la forma de la quilla, el empleo de un sólo mástil para vela cuadrada y el 
timón de codaste, que se corresponde básicamente con la coca hanseática presente en la costa cantábrica en la baja Edad Media. La ausencia de documentación y el mencionado esquematismo de la mayor parte de las embarcaciones nos obligan a proponer una datación aproximada entre fines del siglo XIII y el siglo XV. Es el momento en el que las villas costeras de la fachada atlántica habían ya consolidado su poderío económico y eran capaces de promocionar obras de cierta envergadura en sus antiguos templos, como ocurre en los tres casos principales tratados en esta investigación.

A modo de recapitulación, sobre los posibles motivos que pudieron alumbrar estas representaciones, debemos preguntarnos, en primer lugar, si es posible otorgarles una simbología religiosa. Es bien sabido que en la Edad Media el mar simboliza los peligros y las dificultades de la vida terrenal, comparada con una dificultosa travesía en la que Cristo pilota las almas ${ }^{80}$. Pero la ausencia de un contexto iconográfico que apoye tal función moralizante para nuestros ejemplos, unida a su presencia en villas con un común perfil socioeconómico, relega, en nuestra opinión, este significado, a favor de otras motivaciones más profanas. Proponemos como hipótesis más plausible la relación de estas representaciones con la mencionada y bien documentada actividad de cofradías de mareantes en las villas atlánticas, impulsoras frecuentemente de fundaciones de centros asistenciales para enfermos y peregrinos, que aglutinaban los intereses de comerciantes, pescadores y constructores de barcos. Las cofradías de mareantes presentan un doble cariz: profesional y piadoso. Su profundo sentimiento religioso se liga al intenso riesgo que los mareantes corrían en su trabajo. Y este hecho se manifiesta en la propia advocación bajo la que se protegían estas agrupaciones, como San Telmo, San Nicolás o Santa María, esta última presente en las iglesias que albergan los tres ejemplos principales abordados en nuestra investigación.

${ }^{80} \mathrm{CH}$. VILLAIN-GANDOSSI, Op.cit., p. 51.
Además, en general las cofradías de mareantes contaban con un recinto religioso propio en el que llevaban a cabo sus actos litúrgicos a cargo de los fondos de las mismas: celebrar las festividades patronales, pedir a Cristo un clima favorable a la navegación y rezar por los desaparecidos en alta mar. A veces este recinto específico se concretaba en un templo o ermita con la advocación del santo patrón y otras veces se hacían cargo de una capilla o altar reservado en la parroquia local o en otro templo del municipio. La principal fuente de financiación de las cofradías eran las aportaciones de sus propios integrantes y cada embarcación contribuía según las necesidades de cada momento, como el arreglo o dotación de sus espacios religiosos ${ }^{81}$. En este contexto debió ser frecuente que dejaran constancia iconográfica de este patrocinio. Por último, ya hemos sugerido el mecenazgo artístico individual por parte de personajes enriquecidos con la navegación, caso de las embarcaciones del sepulcro de Noia, sin que este hecho impida encuadrar a estos particulares en una colectividad del tipo de las cofradías bajomedievales.

Para concluir debemos insistir en que la apertura del comercio marítimo atlántico fue un claro cauce de difusión de corrientes artísticas. Si bien la historiografía se ha centrado sobre todo en las relaciones establecidas entre el arco atlántico francés y la costa española, no son tan abundantes los estudios comparativos entre las costas cantábrica y portuguesa. Pero se trata de áreas que cuentan con importantes estudios históricos que constatan las estrechas relaciones comerciales entre asturianos, gallegos y portugueses. Las relaciones comerciales marítimas entre

${ }^{81}$ J.I. ERKOREKA GERVASIO, "La cofradía de mareantes: una institución común a los enclaves costeros del atlántico peninsular", en Actas do simposio de historia maritima do século XII ao XVI, Pontevedra, 2003, pp. 4560; J.I. RUIZ DE LA PEÑA SOLAR, "Solidaridades profesionales en las ciudades de la corona de Castilla...", pp. 141-162 y B. FERNÁNDEZ RODRÍGUEZ, "La plasmación de la religiosidad de los hombres del mar: sus templos", en Actas do simposio de historia maritima do século XII ao XVI, Pontevedra, 2003, pp. 221-231, p. 222. 
Oporto y la costa gallega en época medieval han sido estudiadas ya por E. Ferreira y por otros autores que han fijado entre Oporto y Pontevedra tres sectores de unión: el pescado, la sal y la construcción naval ${ }^{82}$. Por otro lado, sobre los contactos comerciales entre asturianos y portugueses en la baja Edad Media hemos mencionado ya algunos testimonios. A medida que avanzamos en el tiempo se hace más abundante la documentación de mareantes asturianos en las rutas del gran comercio atlántico y viceversa. Así en 1476 los Reyes Católicos dan permiso a los mercaderes de Asturias para traer sal de Francia y Portugal ${ }^{83}$. En la franja geográfica que nos interesa se han localizado además interesantes acuñaciones portuguesas que evidencian las relaciones comerciales entre la costa oriental asturiana y el reino de Portugal, fechadas en el siglo $\mathrm{XV}^{84}$.

Sin duda la apertura de Asturias al comercio atlántico trajo consigo un intercambio cultural importante con las villas costeras relacionadas con sus principales puertos. En el plano artístico estos contactos económicos dejaron una huella profunda en alguno de

${ }^{82}$ E. FERREIRA PRIEGUE, Galicia en el comercio marítimo medieval...; A. DE OLIVEIRA, “Do Porto a Pontevedra (XIII-XVII)...". A mediados del siglo XV se documenta un tal Joao da Noia como intermediario o comisario comercial entre Oporto y Bizcaya (Ibídem, p. 125).

${ }^{83}$ J.I. RUIZ DE LA PEÑA SOLAR y M. I. GONZÁLEZ GARCÍA, Op.cit., doc. ํㅡㄴ.

${ }^{84}$ M.T. COSTALES GARCÍA, M. FERNÁNDEZ MIER y M.A. PEDREGAL MONTES, "Moneda medieval en Asturias. Hallazgos en Santa María de Tina y San Salvador de Valdediós", Asturiensia Medievalia, $\mathrm{n}^{\mathrm{o}}$ 7, 1993-94, pp. 57-84; O. REQUEJO PAGÉS, A. MARTÍNEZ VILLA y M. JIMÉNEZ, “Excavaciones arqueológicas en el conjunto monumental de Valdediós (Villaviciosa), 1988-1989", Excavaciones arqueológicas en Asturias 1987-1990, Oviedo, 1992, pp. 179-182, p. 182. nuestros templos medievales en los que se descubren motivos ornamentales ajenos a las tradiciones autóctonas y coincidentes con los que se conservan en ciertos edificios de las costas francesas e inglesas. Un ejemplo de este motivo son las cabezas rostradas características del Románico de Villaviciosa, que aparecen en la costa de Gran Bretaña ${ }^{85}$ o los gloutons de ciertos templos románicos del Oriente asturiano, de clara filiación franca, presentes en algunas iglesias del Poitou y de la Charente-Maritime ${ }^{86}$. Junto a estos ejemplos más tempranos podríamos situar los relieves de las naves de Llanes y Oporto, tan similares y encontrados en dos puertos geográficamente tan alejados.

Como ha destacado M. Mollat, el mar ha sido siempre más un vínculo que un factor de separación y favoreció la conformación de una cultura naval propia, que se manifestaba en los ritmos de vida profesional, familiar y social ${ }^{87}$. En nuestra opinión, esa cultura marítima o koiné atlántica queda reflejada también en las modestas manifestaciones artísticas como las que hemos tratado en esta investigación.

85 E. FERNÁNDEZ GONZÁLEZ, “La cabezas rostradas. Un tema ornamental en el Románico de Villaviciosa", Asturiensia Medievalia, nº 3, 1979, pp. 341-364.

${ }^{86}$ I. RUIZ DE LA PEÑA GONZÁLEZ, Arquitectura religiosa...

${ }^{87}$ M. MOLLAT, Europa y el mar en el espacio y en el tiempo, Barcelona, 1993, p. 60. Vid. también B. ARIZAGA BOLUMBURU, J.A. SOLÓRZANO TELECHEA, L. H.J. SICKING, "Las sociedades portuarias medievales", en J.A. SOLÓRZANO TELECHEA, M. BOCHACA, A.A. AGUIAR ANDRADE (eds.), Op.c.it., pp. 1318 y en la misma obra colectiva M. BOCHACA y A.A. AGUIAR ANDRADE, "Regards croisés sur les "gens de mer" dans les villes de l'Europe atlantique au Moyen Âge", pp. 359 y siguientes. 